\title{
Home Equity Lending, Credit Constraints and Small Business in the US
}

\author{
by
}

\author{
William D. Lastrapes \\ University of Georgia \\ Ian Schmutte \\ University of Georgia \\ Thor Watson \\ University of Georgia
}

CES 20-32

October, 2020

The research program of the Center for Economic Studies (CES) produces a wide range of economic analyses to improve the statistical programs of the U.S. Census Bureau. Many of these analyses take the form of CES research papers. The papers have not undergone the review accorded Census Bureau publications and no endorsement should be inferred. Any opinions and conclusions expressed herein are those of the author(s) and do not necessarily represent the views of the U.S. Census Bureau. All results have been reviewed to ensure that no confidential information is disclosed. Republication in whole or part must be cleared with the authors.

To obtain information about the series, see www.census.gov/ces or contact Christopher Goetz, Editor, Discussion Papers, U.S. Census Bureau, Center for Economic Studies 5K038E, 4600 Silver Hill Road, Washington, DC 20233, CES.Working.Papers@census.gov. To subscribe to the series, please click here. 


\begin{abstract}
We use Texas's constitutional amendment in 1997 that expanded the scope of home equity loans as a source of exogenous variation to estimate the effects of relaxing credit constraints on small businesses. We find, using standard panel data methods and restricted-use microdata from the US Census Bureau, that the Texas amendment increased the use of home equity finance by small businesses, increased new business and job creation and reduced establishment exit and job loss. The effects are larger and significant for businesses with fewer than ten employees.
\end{abstract}

Keyword: natural experiment, Texas, entrepreneur, difference-in-differences

JEL Classification: M2, M13, R0, E0

\footnotetext{
* Any views expressed are those of the authors and not those of the U.S. Census Bureau. The Census Bureau's Disclosure Review Board and Disclosure Avoidance Offcers have reviewed this information product for unauthorized disclosure of confidential information and have approved the disclosure avoidance practices applied to this release. This research was performed at a Federal Statistical Research Data Center under FSRDC Project Number 1085 (CBDRB-FY20-P1085-R8420, CBDRB-FY20-P1085-R8419, CBDRB-FY20- P1085-R8404, CBDRB-FY19-P1085-R8394, CBDRB-FY19-P1085-R8295, and CBDRB-FY19-P1085-R8175). Funding for this research was provided by the Bonbright Center for the Study of Regulation at the University of Georgia. We are grateful to commentators at the 2019 ARDC Annual Research Conference, Melissa Banzhaf, Julie Hotchkiss and Barry Hirsch for comments and support.
} 


\section{Introduction}

This paper provides evidence on the effects of credit constraints on small business activity in the US, using as a natural experiment the timing of a constitutional amendment in Texas in 1997 that relaxed severe restrictions on home equity loans. Since the work of Abdallah and Lastrapes (2012), Texas's amendment has been exploited as a source of exogenous variation in credit constraints - and interpreted as a credit supply shock - to study the role of financial market imperfections in a wide variety of contexts. ${ }^{1}$ To examine the role of credit constraints for small business, we use restricted access business data from the Census Bureau to compare small business outcomes - new business creation, exits of existing firms, job creation and destruction, and job reallocation - before and after the amendment in Texas. We rely on difference-in-differences methods to isolate causal effects of Texas's credit supply shock on these outcomes.

It is well understood that small businesses and entrepreneurs play an important role in the US economy. According to the Census Bureau's Business Dynamics Statistics (which is derived from the Longitudinal Business Database), businesses with fewer than ten employees accounted for about three-quarters of all firms that hire workers, employed one-eighth of all workers and was responsible for one-quarter of net job growth annually on average over the period 1992-1997. The typical start-up company is small, employing four to six workers in its first year. Unlike large firms and corporations, small firms and would-be entrepreneurs are likely to face binding constraints on borrowing to finance business activity (Schmalz et al., 2017). For example, the National Small Business Association (NSBA) year-end and mid-year reports over the past decade claim that around $30 \%$ of respondents to the NSBA's routine survey of entrepreneurs cannot receive 'necessary' funding for their business. And the 2012 NSBA Small Business Access to Capital Survey reported that $45 \%$ of small business owners who were denied a loan could not obtain a loan because of a low credit score or insufficient collateral. Debt finance, collateralized by housing equity, is the most common form of external

\footnotetext{
${ }^{1}$ See for example Zevelev (2020), Kumar and Liang (2019), Kumar (2018), and Stolper (2015).
} 
finance for individuals running their own business or starting a new one (Robb and Robinson, 2014). Determining if, and the extent to which, small firms are credit-constrained adds to our knowledge about the role of financial market imperfections and has important implications for theory and policy. At the same time, we can gain a better understanding of how housing markets spill-over into the wider economy.

Before 1998, households, small business owners and entrepreneurs in Texas were unable to use equity in their homes to support borrowing for consumption or to finance business ventures. Until then, the Texas State Constitution prohibited mortgage lending for all but a very limited set of expenditures, such as the original purchase of the house and home improvements. But citizens in the state amended their constitution in 1997 to relax these restrictions, thereby providing a new source of funding for private sector activity. At the time of this amendment, no other state in the US restricted home equity loans for general purposes, including for use as collateralizing small business loans, as strictly as Texas.

We interpret this political event in Texas as an exogenous relaxation of credit constraints for the state's entrepreneurs and small businesses, and one with the potential to greatly increase the supply of credit. Contemporary accounts estimate home equity in the state during the 1990's at up to $\$ 200$ billion, implying a range of collateralized lending of $\$ 4$ billion to $\$ 10$ billion annually (Abdallah and Lastrapes, 2012, p. 118). Whether the timing of this event is exogenous is a matter of judgment, since there was no random assignment of 'treatment' across agents; however, Abdallah and Lastrapes (2012, p. 100), through a careful reading of the circumstances of the amendment's enactment, provide supporting evidence that the amendment was an incidental source of variation in credit availability rather than a response to the demand for credit. As such, the event qualifies as a natural experiment and allows us to disentangle the effects of changes in credit supply from those of credit demand using a difference-in-differences empirical strategy. Abdallah and Lastrapes (2012), using similar methods but different data, estimate that this surge in credit availability led to an increase in state- and county-wide retail sales in Texas of 2 to 7 percent, but do not study 
the potential impact on business activity.

The primary source for the small business data used in our main analysis is the Longitudinal Business Database (LBD) compiled by the US Census Bureau. We use these data to construct a balanced panel of 159 Texas and non-Texas counties from 1992 to 2003 - a period spanning the constitutional amendment date - for annual rates of business creation and destruction, and job creation and destruction. This data set is a rich source of information covering the universe of registered business establishments in the US. We also use the Bureau's Survey of Business Owners (SBO) in 1992 and 2007 to examine a prior question, the answer to which aids the interpretation of the main results: whether the Texas amendment increased the incidence of home equity loans by small business owners to start, acquire or expand their business. Both the LBD and SBO are restricted-use microdata requiring special permission from the Census Bureau to ensure confidentiality. We also rely on public-use data to construct control variables and to help sort out the potential economic mechanisms driving the reduced form results. We describe these data in more detail in section 2 of the paper.

Our empirical modeling strategy and results are reported in section 3. We provide the first evidence that the Texas amendment directly affected the use of home equity as a source of funding for small business activities. Using the SBO data, we find that 5.1 percent of business owners outside Texas reported using home equity in 1992, but that just 0.3 percent did in Texas. By 2007, Texas business owners were using home equity at the same rate as the rest of the country: 6.6 versus 6.8 percent. Clearly, the Texas law was very effective in shutting down the use of home equity to finance business investment. This finding holds up in our more formal analysis, which controls for fixed effects and other control variables. The findings are important, not just for our study, but for any analysis that assumes first-order effects on borrowing behavior to motivate the timing of the Texas amendment as an instrument for relaxing credit constraints.

We also find that small business dynamics and employment were significantly affected by the amendment, with business and job creation rising and destruction falling. These 
beneficial effects were larger for small establishments, which is consistent with the notion that the former tend to be more credit constrained than the latter. These findings could be due either to a supply-side channel, where credit availability reduces finance costs for small businesses, or a demand-side channel, where credit availability enhances small business through enhanced purchasing power of households in buying their products, as suggested by the findings of Abdallah and Lastrapes (2012). Using sub-samples to identify sensitivity to treatment, we conclude that the evidence shown in section 3 leans more heavily toward supply-side factors as driving our reduced form results.

The literature on credit constraints and small business is vast. ${ }^{2}$ The extant work closest to ours is Kerr et al. (2019), which has similar aims, relies on data from the SBO and LBD (although not exclusively) and exploits the Texas credit natural experiment in the first part of their paper. Our work strongly complements theirs, answering some questions from the data that they do not. They focus on the role of housing prices as a driver of the amendment's effect, but most significantly, their paper ignores the effects of the amendment on business exit and job destruction rates, focusing exclusively on birth and creation rates like most of the literature in this area. Ignoring exit and destruction downplays local equilibrium effects and forecloses any inference regarding net effects of credit availability on small businesses. We show in our first-stage analysis that the Texas amendment actually did increase home equity lending for small business, a result not documented by Kerr et al. (2019). We provide supporting evidence for the effectiveness of the natural experiment by showing equal pretreatment trends. And finally, we use triple difference-in-differences models to present robust evidence for whether supply or demand channels dominate. Kerr et al. (2019) speculate on the underlying economic mechanisms driving the results, but provide little evidence on these mechanisms using the LBD, although they explore these issues with another data set.

\footnotetext{
${ }^{2}$ Examples include Nykvist (2008), Johansson (2000), Hurst and Lusardi (2004), Evans and Jovanovic (1989), Jensen et al. (2014), and Lelarge et al. (2010)
} 


\section{Data}

The Census Bureau's Longitudinal Business Database (LBD) tracks establishments and firms that have at least one paid employee. The LBD is based on an edited version of the Census Business Register, which the Bureau uses as a sampling frame for all economic surveys. Using information from other sources, the LBD tracks establishments and firms consistently over time in a way that addresses changes in ownership. The longitudinal consistency makes it possible to track when business are born and when they die. The LBD also includes information about payroll and employment, as well as industry and location. From these data we construct annual, county-level aggregates of the main variables of interest. ${ }^{3}$

The LBD records an individual establishment's birth year as the first year it appears in the Bureau's records. Total births in county $i$ during year $t, b_{i t}$, is the number of establishments newly formed in that county during year $t$, computed by adding up all establishments with birth year $t$ in county location $i$. Likewise, total establishment deaths in county $i$ year $t, d_{i t}$, is the sum of firms in that county for which the last year the Bureau observes the firm's existence from these sources is year $t$. We convert these measures to rates, following the standard practice of the Census Bureau, ${ }^{4}$ by normalizing these flows on the two-year average of total number of firms for county $i$ to obtain entry and exit rates, respectively:

$$
\begin{aligned}
& E R_{i t}=\frac{b_{i t}}{1 / 2\left(n_{i t}+n_{i, t-1}\right)} \\
& X R_{i t}=\frac{d_{i t}}{1 / 2\left(n_{i t}+n_{i, t-1}\right)}
\end{aligned}
$$

where $n_{i t}$ is the total number of firms in the sample in county $i$, year $t$.

With respect to the labor market, we directly observe from the LBD the number of paid employees on payroll in March for each firm and each year. To measure job creation and destruction at the county level, both flow concepts as with firm births and deaths, we

\footnotetext{
${ }^{3}$ For additional details see census.gov/programs-surveys/ces/data/restricted-use-data/longitudinalbusiness-database.html and Jarmin and Miranda (2002).

${ }^{4}$ www.census.gov/programs-surveys/bds/documentation/methodology.html and Davis et al. (1996).
} 
compute year-to-year changes in this employment measure for each firm, then aggregate. The number of new jobs created in county $i$ and year $t, j c_{i t}$, is the sum of all employment increases from year $t-1$ to $t$ for expanding firms in that county, including new jobs from firm births. Jobs destroyed, $j d_{i t}$, is the sum of all job decreases coming from contracting firms in the county-year, including losses from firm deaths. To be specific,

$$
\begin{gathered}
j c_{i t}=\sum_{h=1}^{n_{i t}}\left(E_{i h t}-E_{i h, t-1}\right), \text { for } E_{i h t}-E_{i h, t-1}>0 \\
j d_{i t}=\sum_{h=1}^{n_{i t}}\left|E_{i h t}-E_{i h, t-1}\right|, \text { for } E_{i h t}-E_{i h, t-1}<0
\end{gathered}
$$

where $E_{\text {iht }}$ is the level of employment in establishment $h$ in county $i$ in (March of) year $t$. We again convert to relative magnitudes using a similar base as firm births and deaths:

$$
\begin{aligned}
J C R_{i t} & =\frac{j c_{i t}}{1 / 2\left(E_{i t}+E_{i, t-1}\right)} \\
J D R_{i t} & =\frac{j d_{i t}}{1 / 2\left(E_{i t}+E_{i, t-1}\right)}
\end{aligned}
$$

where $E_{i t}=\sum_{h=1}^{n_{i t}} E_{i h t}$. We also compute a county's excess reallocation rate as

$$
E R R_{i t}=J C R_{i t}+J D R_{i t}-\left|J C R_{i t}-J D R_{i t}\right|
$$

The excess reallocation rate measures job reallocation above that needed to support net employment growth.

Table 1 reports sample means and standard deviations of these variables for the time prior to the amendment separately for Texas and non-Texas counties in states bordering Texas and bordering the border states (our second control group described below). There are no major differences in these statistics across the two samples.

The Survey of Business Owners (SBO) is conducted every five years on the same schedule as the Economic Census. Prior to 1997, the survey was called the Characteristics of Business 
Owners (CBO). Both surveys target the universe of businesses that filed tax forms reporting business income, with or without employees. The survey "provides basic economic, demographic, and sociological data on the characteristics of minority, women, and non-minority male business owners and their business activities" (Bureau, 1992). However, the exact questions and sample change from year to year. We are primarily interested in the response to a single question that was asked in the 1992 CBO and the 2007 SBO: "For the current owners(s), as of December [year], what was the source(s) of capital used to start or acquire this business?" In those years, one of the available options was "Personal/family home equity loan".5

Table 2 shows sample proportions from the survey from the entire sample of firms (not broken down by treatment and control) for the years 1992 and 2007. There are over one million weighted observations for each year. The first three rows reflect answers to question \#66 about the source of finance; the remaining are for demographic features of the data that are used as controls in the analysis of the first subsection of section 3. The proportion of businesses using home equity loans was generally steady, rising by about 1.7 percentage points from 1992 to 2007. Over the same time period, there was more than a ten percentage point rise in 'no loans' used to start or acquire a business at the expense of other loans.

We also use publicly available data to construct county-level variables for each year, including them in the difference-in-difference analysis to control for time-varying factors that influence local business outcomes that differ on average between counties inside and outside Texas. From the Census Bureau's Population Estimates we obtain county-level population estimates by gender, race, and ethnicity. From the Bureau of Labor Local Area

\footnotetext{
${ }^{5}$ The relevant question is \#66 in Figure 1, which is a replica of p. 7 of the survey in 2007. We compare responses to this question to question 14c from the $1992 \mathrm{CBO}$ form 1, which has slightly different wording but is essentially the same. Comparability over time in the underlying population is addressed in technical documentation provided by the Census Bureau (Bureau, 1992, 2006) and summarized in Appendix A of Fairlie and Robb (2008). Between 1992 and 2002 Census eliminated businesses with receipts under $\$ 1000$ from the sample, and added C corporations. The sectoral scope of the survey also expanded between 1992 and 2002 to include information, FIRE, real estate, and health-care. For our microdata analysis we use comparable samples adjusted by reweighting. Fairlie (2013) and Fairlie and Robb (2008) demonstrate the feasibility of using the restricted $\mathrm{CBO}$ and SBO to study changes over time in characteristics of small businesses. Question \#70 in the 2007 form has no analogue in the 1992 survey.
} 
Unemployment Statistics we obtain unemployment rate and labor force figures. From the Internal Revenue Services' Statistics of Income we obtain adjusted gross income and wages, and from the Federal Housing Finance Agency's Annual House Price Indexes we obtained county-level housing price indices, and from the Federal Financial Institutions Examination Council's Mortgage Lending Assessment Data Files we obtain median housing prices by county. For additional details about the data, see Appendix A.

In the analysis below, we consider individual establishments in Texas to be in the treatment group, while those outside Texas are in the control group. For the main results we select three sets of control groups: 1) counties located in states in the Census's South region (Delaware, Maryland, West Virginia, Virginia, Kentucky, North Carolina, Tennessee, South Carolina, Georgia, Alabama, Mississippi, Florida, Louisiana, Arkansas and Oklahoma), 2) counties located in a border state of Texas or a border state of a Texas border state, and 3) counties located in a border state of Texas plus Colorado plus Kansas. ${ }^{6}$ For both treated and untreated samples we included counties with a population of at least 30,000 and at least 100 annual housing transactions for each of the years in our sample, and counties for which we consistently observed all control variables. 47 counties from Texas are included, and 112 counties in the non-Texas control group. Generally, none of our results are sensitive to the control group used, so we report results primarily for the second group. ${ }^{7}$ Figure 2 specifies both the control and treatment counties in our empirical work.

\section{Results}

We ask three empirical questions regarding the credit supply shock in Texas: 1) did the Texas amendment increase the incidence of home equity loans for business? 2) did the Texas amendment affect business outcomes and do such effects depend on firm size? and 3) were these effects the results of supply-side or demand-side factors?

\footnotetext{
${ }^{6}$ We could not limit the third control group to only Texas border states because of disclosure restrictions.

${ }^{7}$ Results for the other two control groups are reported in Appendix B.
} 


\subsection{Did the Texas amendment increase home equity loans?}

As we note in the introduction, the survey data from the SBO imply that $0.3 \%$ of Texas business owners used a home equity loan to start or acquire their business in 1992, compared to $5.1 \%$ for non-Texas owners, strongly suggesting that the law was binding for Texas entrepreneurs. In 2007, home-equity usage caught up in Texas: $6.6 \%$ of businesses in the state relied on a home-equity loan - a large rise from 1992 - while $6.8 \%$ used such loans outside of Texas, a much smaller increase. The fact that Texas 'looks like' other states after the amendment is firm prima facie evidence that the amendment significantly relaxed borrowing constraints in Texas, but we provide more formal evidence from a difference-in-differences specification in the context of a linear probability model:

$$
z_{h t}=\alpha_{0}+\alpha_{1} \phi_{t}+\delta \tau_{h} \phi_{t}+\beta X_{h t}+\theta_{s}+\epsilon_{h t}
$$

for $h=1, \cdots, N$ and $t=1992,2007 . N$ is the total number of firms in the survey, $\tau_{h}=1$ if firm $h$ resides in Texas and 0 otherwise, $\phi_{t}=1$ for $t=2007$ and 0 for 1992, $\theta_{s}$ is a state fixed effect, and the dependent variable $z_{h t}=1$ if firm $h$ reports the use of home equity loans and 0 otherwise. The control variables in $X_{h t}$ include primary business-owner demographics (age, sex, race, education) and establishment characteristics (single owned, franchise, exporter, non-employment history, industry sector).

Table 3 shows that the initial inference holds up, even after controlling for demographic factors and state fixed effects. All else the same, the proportion of Texas business owners using home equity loans rose by almost 7 percentage points relative to non-Texas businesses, although the use of such loans remained lower on average in Texas. As we might expect, the greater incidence of home-equity loans reduced the use of other loans. The survey data do not allow us to determine whether the dollar value of new home-equity loans simply replaced the lost value of other loans. Yet we can safely infer that, even if home equity loans replaced other loans one-for-one in value, the former are presumably less expensive alternatives which 
could have important benefits for credit-constrained firms.

Because we have only one treated group and two time periods, we rely on the method of Ferman and Pinto (2019) to ensure that our results are robust. Their method is an extension of the cluster residual bootstrap with the null imposed, with residuals corrected for heteroskedasticity. Table 4 reports two sets of results for each model: a standard cluster residual bootstrap and a separate bootstrap with the adjustment (both with 10,000 draws). The null hypothesis is that the true point estimate for $\delta$ is what we estimated it to be in Table 3. The $p$-values in Table 4 are all, but for one case, less than $5 \%$, which supports the robustness of our findings.

In sum, we document a robust fact that the Texas constitutional amendment freeing up the use of home equity as collateral did indeed relax binding constraints on borrowing by small businesses in Texas. This finding helps make sense of our results in the next sub-section, but also generally supports other research that relies on the amendment as a natural experiment.

\subsection{Did the Texas amendment affect small business dynamics and employment?}

We examine this question in two steps. First, we estimate the broader effect of the amendment on all businesses in Texas using a standard difference-in-differences design with two-way fixed effects. We then split the sample by firm size, estimating a triple differencein-differences model and adding a size indicator and interaction terms. The motivation to consider differential effects on large and small establishments is that the latter are more likely to face binding credit constraints than the former.

The difference-in-differences model is

$$
y_{i t}=\alpha_{0}+\alpha_{1} \tau_{i}+\alpha_{2} \phi_{t}+\delta \tau_{i} \phi_{t}+\beta X_{h t}+\epsilon_{i t}
$$

for $i=1, \cdots, 159$ counties (47 in Texas and 112 outside of Texas) and $t=1992$ to 2003, a total of 1,908 county/year observations. We estimate the model alternately for dependent variables $y=E R, X R, J C R, J D R, E E R$, where these variables are constructed using observations 
from all businesses in the sample. $\tau_{i}$ is set to one for Texas counties and $\phi_{t}$ is set to one post-1997; so $\delta$, the treatment effect, measures the difference between how Texas outcomes change after the amendment to changes in non-Texas counties. $X_{i t}$ is a set of geographic and demographic controls; in particular, county-level proportion of males, race proportions, unemployment rate, population growth rate and wage growth rate. ${ }^{8}$

Table 5, top panel shows the results for two cases, without control variables $(\beta=0)$ to the left and with controls to the right. Focusing on the latter, we find that the amendment has a statistically significant positive effect on firm entry and negative effect on firm exit, both findings consistent with a loosening of binding credit constraints. The estimates imply that after the amendment the rate of new business creation in Texas counties was almost 18 basis points higher than in the control counties; based off of the pre-amendment entry-rate sample mean of around $5 \%$ (Table 1), this rise is equal to a $3.5 \%$ increase. Although this increase is non-trivial, it is only $17 \%$ of the standard deviation of entry rates in pre-amendment Texas (1.067). The coefficient estimate on exit is of similar absolute magnitude, but reflects only a $1.75 \%$ increase off of the higher mean exit rate. The estimates for the labor market variables, $J C R, J D R$ and $E E R$ are of consistent signs, but are not significantly different from zero. The relatively small effects are consistent with the findings of Kerr et al. (2019).

Given that small businesses are more likely to face credit constraints than larger ones, we split the sample of business outcomes into rates across firm size. Let $s_{j}=1$, where $j$ indexes size category, indicate an entry/exit or creation/destruction rate computed from establishments hiring fewer than ten employees - we call these firms 'small'. ${ }^{9}$ For example, for $s_{j}=1 E R_{i j t}$ is the entry rate computed by adding up all births in county $i$ during year $t$ for only small firms so defined. $s_{j}$ is zero when $j$ does not correspond to a small firm. We

\footnotetext{
${ }^{8}$ Our results are robust to minor variations on the control variables, such as using the employment-topopulation ratio instead of the unemployment rate and lagged values instead of contemporaneous ones.

${ }^{9}$ The ten-employee threshold to distinguish small versus large firms is common in the literature; for example, see Table 7 in Kerr et al. (2019). The firm size classification used by Census and the BLS goes Size Class 1 (1-4 employees), Size Class 2 (5-9 employees), Size Class 3 (10-19), etc. The average startup has between 4-6 employees (as mentioned in the introduction), so the average new employer would appear in either size class 1 or 2 ; hence, we combined the two size classes.
} 
then estimate the following triple difference-in-differences specification:

$$
\begin{aligned}
y_{i j t} & =\alpha_{0}+\alpha_{1} \tau_{i}+\alpha_{2} s_{j}+\alpha_{3} \phi_{t}+\alpha_{4} \tau_{i} s_{j}+\alpha_{5} s_{j} \phi_{t}+\delta_{1} \tau_{i} \phi_{t}+\delta_{2} \tau_{i} s_{j} \phi_{t} \\
& +\beta X_{i j t}+\epsilon_{i j t} .
\end{aligned}
$$

We use the same sample as before, but since we have dichotomized it by two size categories the number of county-year observations double to over $3,800 .{ }^{10}$ Given this specification, $\delta_{1}$ is the change in non-small Texas firms from before to after the amendment minus the change in non-small, non-Texas firms; for small firms the analogous treatment effect is the sum $\delta_{1}+\delta_{2}$, so $\delta_{2}$ is the differential treatment effect between small and non-small firms. These estimates are reported in the bottom panel of Table 5 .

The inference is clear - the amendment's effects are driven primarily through its impact on small firms. The positive response of the entry rate almost doubles for small firms to 33 basis points while the response for non-small firms is essentially zero. Instead of declining by 17.6 basis points for all firms as implied by model (2), the small business exit rate declines by almost 58 basis points. The treatment effect for small businesses job creation rate is 77 basis points $\left(\delta_{1}+\delta_{2}\right)$, an increase of $5.5 \%$ off the full sample mean job creation rate of $14 \%$. The standard errors indicate that these treatment effects are statistically significantly different for small firms compared to non-small firms. ${ }^{11}$

The excess reallocation rate rises by almost two percentage points (200 basis points) for small firms only, while it falls about half a percentage point among larger firms. The excess reallocation rate is an indicator of business dynamism, as it measures the movement of economic activity from contracting to expanding firms. This finding suggests that credit constraints may have been hindering productive entrepreneurs from entering or expanding their businesses prior to the law change.

\footnotetext{
${ }^{10}$ Note that we are not splitting the sample in the usual sense of relaxing a restriction that equates the effects of large and small firms. We recompute the dependent variables for the different size categories, thereby increasing the sample size.

${ }^{11}$ Disclosure rules prevent us from releasing summary statistics for our size cuts.
} 
Figures 3 and 4 compare trends before and after the amendment by replacing the pre-, post-amendment dummy with specific year dummies. The figures are derived from an event study setup where we replace the pre/post dummy and it's interactions (e.g., post*Texas and post*small and post*Texas*small) with a set of T-1 year dummies and their respective interactions, excluding 1997 as the reference year. In the post period, the estimates can be interpreted as year-specific treatment effects; but now relative to 1997 outcomes instead of the average across the pre-period. The similarity of the pre-treatment trends supports our use of the Texas Amendment as a natural experiment, as well as the results in Kerr et al. (2019).

\subsection{Were supply or demand factors at play?}

We now consider whether the reduced-form effects identified in the previous section are primarily due to supply or demand factors. On the supply side, the relaxation of borrowing constraints improves access to credit markets for businesses generally unable to borrow in external capital markets. This improvement reduces the cost of finance and production, thereby enhancing entry and job creation and limiting exit and job destruction. On the demand side, the Texas amendment relaxed constraints not only for businesses, but for consumers as well. Increased overall demand by consumers for small business products and service might induce those businesses to expand or proliferate. Both of these channels could be in operation in the data.

First, note that the differential effects reported above for small and large firms are most consistent with the supply-side channel. If demand-side effects dominate, then increased spending should be proportionately disbursed across the output of both small and large firms, and we should see no differential effect. If the supply channel dominates, small firms are more likely to be sensitive to the increase in credit availability than larger firms with lower-cost finance, so we should expect to see the differential that we report.

We look along two other dimensions to gauge the intensity of the treatment effect in 
order to tease out which channel is dominant. The first distinguishes between businesses that produce goods in 'tradable' versus 'non-tradable' industries. If relaxing home equity loan restrictions primarily affects overall demand, then activity of businesses selling goods in local markets that are not easily traded in other localities - like restaurants - will increase more than for goods tradable outside of Texas - like manufactured goods or software publishers. Supply-side effects dominate if treatment effects do not differ across these groups. The second looks at locational variation in property values. Businesses in areas with high housing prices, all else the same, have greater scope for using home equity to finance their ventures than those in low-value areas. While high-value areas will also exhibit stronger demand-side effects, much of the higher spending is likely to be disbursed out of the area. Thus, businesses in high-value areas will be more sensitive to the treatment effect than those in low-value areas if supply factors are prominent.

As in the previous sub-section, we estimate triple difference-in-differences models of the form of equation (3), where $s_{j}$ is now an indicator binary variable for either tradable or non-tradable sector, or alternately for high or low value property. In the first regression, $s_{j}$ is set to one when the firms used to compute entry, exit, job creation, and job destruction rates are in industries that produce goods that are easily tradable across state borders. ${ }^{12}$ For supply factors to matter more, $\delta_{2}$ (the differential treatment effect for firms selling tradeables) should be statistically insignificant; for demand factors to matter more, $\delta_{2}$ should be negative for entry and job creation rates, and positive for exit and job destruction rates. In the second regression, $s_{j}$ is set to one for firms in high property value areas. ${ }^{13}$ If supply factors are dominant, $\delta_{2}$ (the differential treatment effect for high-property-value areas) should be

\footnotetext{
${ }^{12}$ We use NAICS codes to classify each firm as belong either to tradable, non-tradeable, or other sector following (Mian and Sufi, 2012, Appendix Table 1): "we define a 4-digit NAICS industry as tradable if it has imports plus exports equal to at least $\$ 10,000$ per worker, or if total exports plus imports for the NAICS 4-digit industry exceeds $\$ 500 \mathrm{M}$. Non-tradable industries are defined as the retail sector and restaurants."

${ }^{13}$ The property value classification is based on the median of county home prices for our Texas counties in 1997. This is approximately $\$ 115,000$ in constant 2019 dollars. If a county's median home prices are above $\$ 75,000$ in 1997 (whether in Texas or not) then we consider it a high property value county throughout the analysis. In Texas, this procedures splits Texas counties evenly between low and high classification, whereas almost $28 \%$ of non-Texas counties are are classified as low.
} 
positive for entry and creation and negative for exit and destruction, while for demand it should be statistically zero.

From Table 6 we see that the results from this exercise are mostly consistent with the size regressions, and support the conclusion that supply-side effects dominate. In the top panel, only the $\delta_{2}$ estimate for entry rates is consistent with the demand channel and statistically significant - it reveals that the treatment effect is slightly smaller for firms selling tradable goods. However, this finding is not robust across control groups. The middle panel of the table shows the results for our third non-Texas control group, whereas the top panel uses the baseline second control group. The middle panel reveals that the estimate of $\delta_{2}$ using this alternative control group has a large standard error and is not statistically significant.

The third panel reports the results for which $s_{j}$ is the binary variable measuring high versus low property value areas. This panel supports the dominance of supply-side factors since the estimates of $\delta_{2}$ are consistent with greater small business expansionary effects and smaller contractionary effects for high-value areas. Note that the effects for job destruction and excess reallocation rate are particularly large. But this panel also allows us to more directly compare our results to those of Kerr et al. (2019). In the section of their paper that deals with the Texas amendment, they estimate a variant of our triple diff-in-diff model in equation (3), but find only small effects of house prices on the treatment effect as implied by estimates of their model's parameter analogous to our $\delta_{2}$. We can only speculate as to the reason for the different results, but it may be due to different control groups and their use of house price indices rather than our binary high-low price variable. Whereas the dummy variable approach ignores some variation in house prices, it better allows for potential non-linear effects. They also work with core-based statistical areas instead of counties, which limits their samples to urban and sub-urban areas which, all else the same, lowers the precision of their estimates. 


\section{Conclusion}

We find that the Texas amendment had statistically significant, yet overall modest, effects on small business activity, including job creation and destruction. However, the effect is larger for small establishments, those with fewer than ten employees. Our results support a growing body of evidence that the activity of small and young businesses is hampered by limitations on the availability of credit, particularly housing collateral. We complement much of the recent research on this topic, which has often used changes in house prices, or housing supply elasticities to instrument for collateral availability. Changes in the value of house prices are generally endogenous to business conditions facing entrepreneurs. The Texas amendment, by contrast, resulted in an exogenous shift in the availability of housing collateral and credit for entrepreneurs.

By adding to the ensemble of evidence that collateral constraints matter for small business activity, we contribute to external validity. While of course we cannot extrapolate our results beyond the specific case we study, our results support a class of models that suggest restrictions on collateral inhibit entrepreneurs from growing their businesses. In adding to this evidence, it is particularly meaningful that we are able to distinguish between supply and demand channels. If the Texas amendment only affected small businesses indirectly, through increased consumption demand, we could not say much about the direct importance of credit availability.

Availability of liquidity has been a key policy concern during the current COVID-19 pandemic. The literature our results support suggests that credit constraints may matter a lot for the viability of small and young businesses. We find that increased availability of credit to small businesses increases their likelihood of survival. It is less clear that expanded credit resulted in fewer job losses for the Texas businesses we study. Perhaps most importantly, we find that expanded credit increased business dynamism, as measured through the excess reallocation rate. This finding suggests that some small businesses that are otherwise productive are prevented from expanding owing to credit constraints. If so, 
then many of the small businesses getting hammered by the pandemic and lacking access to credit could otherwise be very productive, implying that the destruction of business wrought by the pandemic is not creative destruction. This line of thinking supports policies that offer subsidized loans or grants to small businesses to help them stay afloat until business conditions return to normal. 


\section{References}

Abdallah, C. S. And W. D. Lastrapes (2012): "Home Equity Lending and Retail Spending: Evidence from a Natural Experiment in Texas," American Economic Journal: Macroeconomics, 4, 94-125.

Bureau, U. C. (1992): “1992 Economic Census: Characteristics of Businesses Owners," Company Statistics Series CBO92-1, U.S. Census Bureau.

— (2006): "Characteristics of Businesses: 2002," Company Statistics Series SB02-00CSCB, U.S. Census Bureau.

Davis, S. J., J. C. Haltiwanger, And S. Schuh (1996): Job Creation and Destruction, MIT Press.

Evans, D. S. And B. Jovanovic (1989): “An Estimated Model of Entrepreneurial Choice under Liquidity Constraints," Journal of Political Economy, 97, 808-27.

FAirlie, R. And A. RoBB (2008): Race and entrepreneurial success: Black-, Asian-, and white-owned businesses in the United States, MIT Press.

FAIRlie, R. W. (2013): "Entrepreneurship, Economic Conditions and the Great Recession," Journal of Economics and Management Strategy.

Ferman, B. And C. Pinto (2019): "Inference in Differences-in-Differences with Few Treated Groups and Heteroskedasticity," The Review of Economics and Statistics, 101, $452-467$.

Hurst, E. And A. Lusardi (2004): "Liquidity Constraints, Household Wealth, and Entrepreneurship," Journal of Political Economy, 112, 319-347.

Jarmin, R. S. And J. Miranda (2002): "The Longitudinal Business Database," Working Paper 02-17, Center for Economic Studies, U.S. Census Bureau. 
Jensen, T. L., S. Leth-Petersen, And R. Nanda (2014): "Housing Collateral, Credit Constraints and Entrepreneurship - Evidence from a Mortgage Reform," NBER Working Papers 20583, National Bureau of Economic Research, Inc.

Johansson, E. (2000): "Self-Employment and Liquidity Constraints: Evidence from Finland," Scandinavian Journal of Economics, 102, 123-34.

Kerr, S. P., W. R. Kerr, and R. Nanda (2019): "House Prices, Home Equity and Entrepreneurship: Evidence from U.S. Census Micro Data," Harvard Business School Working Papers 15-069, Harvard Business School.

Kumar, A. (2018): "Do Restrictions on Home Equity Extraction Contribute to Lower Mortgage Defaults? Evidence from a Policy Discontinuity at the Texas Border," American Economic Journal: Economic Policy, 10, 268-297.

Kumar, A. And C.-Y. Liang (2019): "Credit constraints and GDP growth: Evidence from a natural experiment," Economics Letters, 181, 190 - 194.

Lelarge, C., D. Sraer, And D. Thesmar (2010): "Entrepreneurship and Credit Constraints: Evidence from a French Loan Guarantee Program," in International Differences in Entrepreneurship, National Bureau of Economic Research, Inc, NBER Chapters, 243-273.

Mian, A. R. And A. Sufi (2012): "What explains high unemployment? The aggregate demand channel," NBER Working Paper 17830, National Bureau of Economic Research, Inc.

Nykvist, J. (2008): "Entrepreneurship and Liquidity Constraints: Evidence from Sweden," Scandinavian Journal of Economics, 110, 23-43.

Robb, A. M. and D. T. Robinson (2014): "The Capital Structure Decisions of New Firms," The Review of Financial Studies, 27, 153-179. 
Schmalz, M. C., D. A. Sraer, And D. Thesmar (2017): "Housing Collateral and Entrepreneurship," The Journal of Finance, 72, 99-132.

Stolper, H. (2015): "Home Equity Credit and College Access: Evidence from Texas Home Lending Laws," Columbia University working paper.

Zevelev, A. A. (2020): "Does Collateral Value Affect Asset Prices? Evidence from a Natural Experiment in Texas," Available from SSRN 2815609. 
Table 1: Sample statistics: LBD constructed variables, 1992-1997

\begin{tabular}{|c|c|c|c|c|}
\hline \multirow[b]{2}{*}{ Variable } & \multicolumn{2}{|c|}{ Non-Texas } & \multicolumn{2}{|c|}{ Texas } \\
\hline & mean & st. dev. & mean & st. dev. \\
\hline Entry rate & 4.877 & 1.075 & 5.182 & 1.067 \\
\hline Exit rate & 9.851 & 1.253 & 10.34 & 1.126 \\
\hline Job creation rate & 14.56 & 5.951 & 13.99 & 4.678 \\
\hline Job destruction rate & 13.25 & 6.619 & 12.65 & 5.471 \\
\hline Job reallocation rate & 23.68 & 5.974 & 23.35 & 4.433 \\
\hline
\end{tabular}

There are approximately 672 county-year observations for the nonTexas sample and 282 for the Texas sample. Because of confidentiality restrictions, we report sample statistics only for the limited time sample. Non-Texas states are those in our baseline control group of border and border-to-border states. 


\section{Business}

65 In what year was this business originally established?
$\square$ Before 1980
$\square 2004$
$1980-1989$
$\square 2005$
$1990-1999$
$\square 2006$
$2000-2002$
$\square 2007$
$\square 2003$
$\square$ Don't know

66 A. For the owner(s) as of December 31, 2007, what was the source(s) of capital used to start or acquire this business?

Mark $X$ all that apply.

Personal/family savings of owner(s)

Personal/family assets other than savings of owner(s)

$\square$ Personal/family home equity loan

$\square$ Personal/business credit card(s)

Business loan from federal, state, or local government

$\square$ Government-guaranteed business loan from a bank or financial institution

$\square$ Business loan from a bank or financial institution

Business loan/investment from family/friend(s)

$\square$ Investment by venture capitalist(s) (An early-stage investment in exchange for ownership equity by an individual, outside group, or business not directly involved
in the overall operation and management of the business.)

$\square$ Grants

$\square$ Other source(s) of capital

$\square$ Don't know

$\square$ None needed - Go to 67

B. For the owner(s) as of December 31, 2007, what was the total amount of capital used to start or acquire this business? (Capital includes savings, other assets, and borrowed funds of owner(s)).

$\square$ Less than $\$ 5,000$

$\square \$ 100,000-\$ 249,999$

$\square \$ 5,000-\$ 9,999$

$\square \$ 10,000-\$ 24,999$

$\$ 250,000-\$ 999,999$

$\square \$ 25,000-\$ 49,999$

$\$ 1,000,000$ or more

$\square \$ 50,000-\$ 99,999$

67 In 2007, did this business operate primarily from somebody's home?
$\square$ Yes
$\square$ No

68

In 2007, did this business operate as a franchise?

$\square$ Yes

No

69 In 2007 , did a franchiser own more than $50 \%$ of this business?

Yes

No
70 In 2007, were any of the following sources used to finance expansion or capital improvement(s) for this business? Mark $x$ all that apply.

$\square$ Personal/family savings of owner(s)

$\square$ Personal/family assets other than savings of owner(s)

$\square$ Personal/family home equity Ioan

$\square$ Personal/business credit card(s)

$\square$ Business loan from federal, state, or local government

$\square$ Government-guaranteed business loan from a bank or financial institution

$\square$ Business loan from a bank or financial institution

$\square$ Business loan/investment from family/friend(s)

$\square$ Investment by venture capitalist(s) (An early-stage investment in exchange for ownership equity by an individual, outside group, or business not directly involved in the overall operation and management of the business.)

$\square$ Business profits and/or assets

$\square$ Grants

$\square$ Other source(s) of capital

$\square$ Don't know

$\square$ Did not have access to capital

$\square$ Did not expand or make capital improvement(s)

71 In 2007, which of the following types of customers accounted for $10 \%$ or more of this business's total sales of goods and/or services? Mark X all that apply.

$\square$ Federal government

$\square$ State and local government, including school districts, transportation authorities, etc.

$\square$ Other businesses and/or organizations, including distributors of your product(s)

$\square$ Individuals

72 In 2007, what percent of this business's total sales of goods and/or services consisted of exports outside the United States?
$\square$ None
$20 \%-49 \%$
$\square$ Less than $1 \%$
$50 \%-99 \%$
$\square 1 \%-4 \%$
$100 \%$
$\square 5 \%-9 \%$
Don't know
$\square 10 \%-19 \%$

73 In 2007, did this business establish operations outside the United States?
$\square$ Yes
$\square$ No

74 In 2007, did this business outsource or transfer any business function and/or service to a company outside the United States?
$\square$ Yes
No

$\Theta$

Please turn to the next page to continue.

FORM SBO-1 (01/02/2008) 
Figure 2: Treatment and control counties

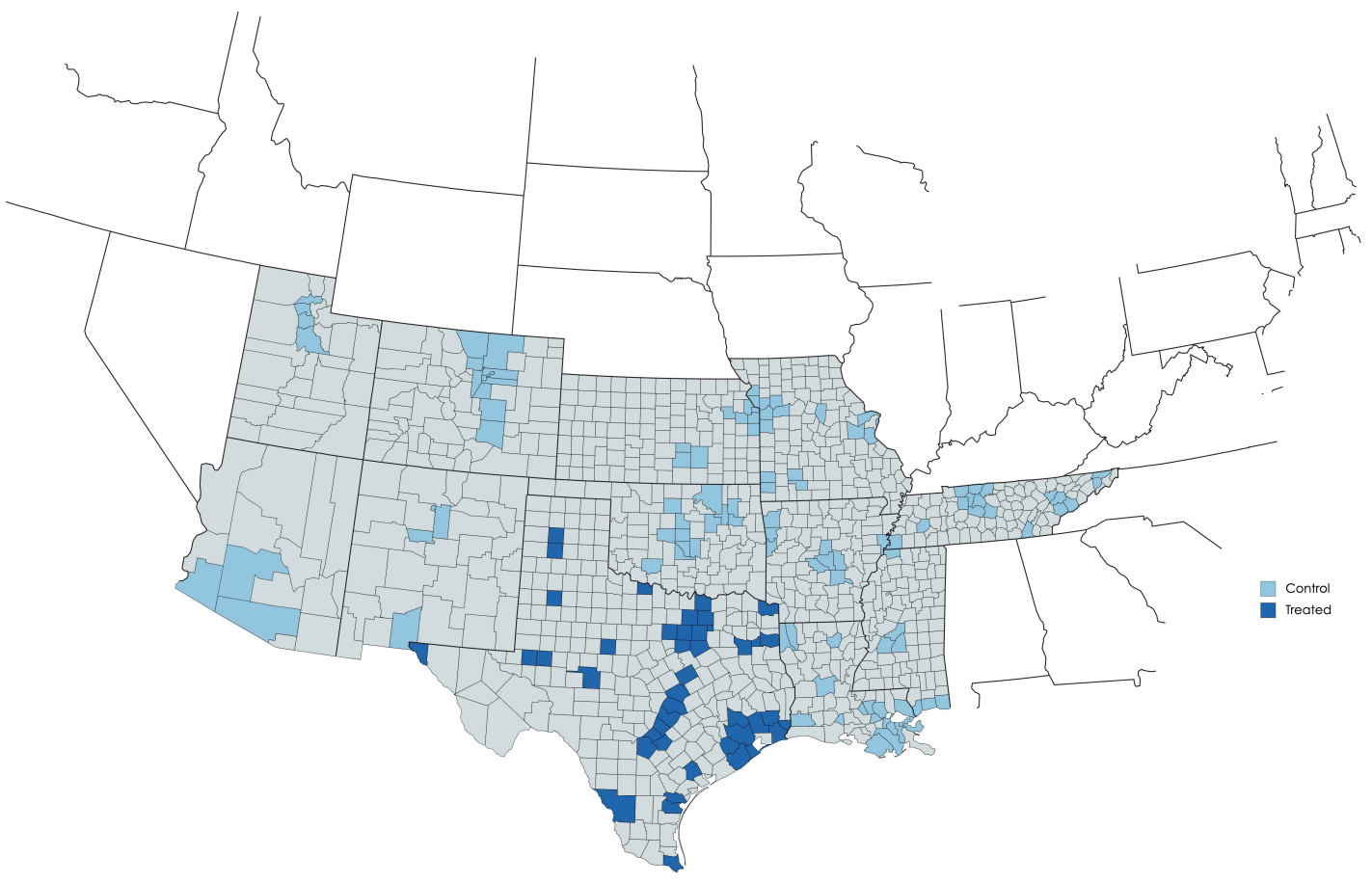

The non-Texas counties are from the second control group: border states of Texas plus border states of a border state 
Table 2: Sample statistics: SBO 1992 and 2007

\begin{tabular}{|c|c|c|}
\hline Variable & 1992 & 2007 \\
\hline Home Loan & 5.04 & 6.77 \\
\hline Other Loan & 43.71 & 31.32 \\
\hline No Loan & 51.25 & 61.91 \\
\hline Age $<35$ & 10.91 & 1.82 \\
\hline $35<$ Age $<54$ & 60.93 & 48.64 \\
\hline Age $>54$ & 28.16 & 49.55 \\
\hline Asian & 4.69 & 5.23 \\
\hline Black & 2.19 & 1.34 \\
\hline Hispanic & 3.43 & 0.20 \\
\hline White & 88.75 & 92.30 \\
\hline Male & 79.97 & 79.33 \\
\hline SomeHS & 9.34 & 3.55 \\
\hline HSGrad & 28.48 & 18.79 \\
\hline SomeCol & 25.18 & 25.88 \\
\hline ColGrad & 13.24 & 25.54 \\
\hline PostCol & 23.75 & 26.24 \\
\hline Franchise & 3.84 & 3.06 \\
\hline Exporter & 0.61 & 2.73 \\
\hline N.E. History & 58.66 & 5.11 \\
\hline Midwest & 16.65 & 21.89 \\
\hline Northeast & 25.34 & 24.21 \\
\hline South & 32.41 & 32.87 \\
\hline West & 25.59 & 21.03 \\
\hline AFFM & 3.75 & 3.33 \\
\hline Construction & 14.06 & 13.68 \\
\hline Manufacturing & 3.87 & 6.07 \\
\hline TCEGS & 3.01 & 3.37 \\
\hline WholesaleTrade & 3.75 & 7.18 \\
\hline RetailTrade & 23.60 & 15.99 \\
\hline FIRE & 5.52 & 8.30 \\
\hline Services & 42.44 & 42.08 \\
\hline Tradable & 3.76 & 6.43 \\
\hline Non-tradable & 26.08 & 20.84 \\
\hline Ambiguous & 70.16 & 72.72 \\
\hline N (Weighted Count) & $1,172,000$ & $1,130,000$ \\
\hline
\end{tabular}

Weighted statistics for single-unit, employer firms in the 1992 Characteristics of Business Owners Survey and 2007 Survey of Business Owners. The data are linked to the LBD to obtain information on industry SIC/NAICS codes. We also check for potential links with the ILBD to ascertain whether a business had a history of being a non-employer. 
Table 3: Effects of Texas amendment on loan use

\begin{tabular}{llll}
\hline Home-equity loans & Model 1 & Model 2 & Model 3 \\
\hline$\delta$ (Texas* post) & $0.0627^{* * *}$ & $0.0626^{* * *}$ & $0.0681^{* * *}$ \\
& $(0.0145)$ & $(0.0136)$ & $(0.0174)$ \\
$\alpha_{2}$ (Texas) & $-0.0514^{* * *}$ & $-0.0273^{* * *}$ & $-0.0298^{* *}$ \\
& $(0.0067)$ & $(0.0081)$ & $(0.0110)$ \\
$\alpha_{1}$ (Post) & $0.0162^{*}$ & $0.0188^{* *}$ & $0.0167^{* *}$ \\
& $(0.0065)$ & $(0.0060)$ & $(0.0064)$ \\
\hline Other loans & Model 1 & Model 2 & Model 3 \\
\hline$\delta$ (Texas*post) & $-0.0603^{*}$ & $-0.0723^{* *}$ & $-0.0953^{* * *}$ \\
& $(0.0243)$ & $(0.0233)$ & $(0.0228)$ \\
$\alpha_{2}$ (Texas) & $0.149^{*}$ & 0.0684 & 0.0746 \\
& $(0.0610)$ & $(0.0793)$ & $(0.0820)$ \\
$\alpha_{1}$ (Post) & $-0.115^{* * *}$ & $-0.108^{* * *}$ & $-0.0961^{* * *}$ \\
& $(0.0201)$ & $(0.0168)$ & $(0.0203)$ \\
\hline State FE & No & Yes & Yes \\
Controls & No & No & Yes \\
N (Weighted Count) & $2,302,000$ & $2,302,000$ & $2,302,000$ \\
\hline
\end{tabular}

Cluster-robust standard errors at the state level in parentheses. Weighted regression results for single-unit firms. Controls include owner demographics (age, sex, race, education) and firm characteristics (single owned, franchise, exporter, non-employment history, industry sector). $* p<0.10, * * p<0.05, * * * p<0.01$

Table 4: Effect of Texas amendment on loan use - FP Robust Check

\begin{tabular}{llcc} 
Home equity loans & Model (1) & Model (2) & Model (3) \\
\hline P-value w/o adjustment & 0.03658 & 0.03717 & 0.02538 \\
P-value w/ FP adjustment & 0.04545 & 0.02293 & 0.00274 \\
N (Simulations) & 100000 & 100000 & 100000 \\
\hline Other loans & Model (1) & Model (2) & Model (3) \\
\hline P-value w/o adjustment & 0.1015 & 0.0385 & 0.0181 \\
P-value w/ FP adjustment & 0.0013 & 0 & 0 \\
N (Simulations) & 100000 & 100000 & 100000 \\
\hline
\end{tabular}

Reported p-values are from cluster residual bootstrapping simulations with and without a heteroskedasticity correction applied to the residuals outlined by Ferman and Pinto (2019). 


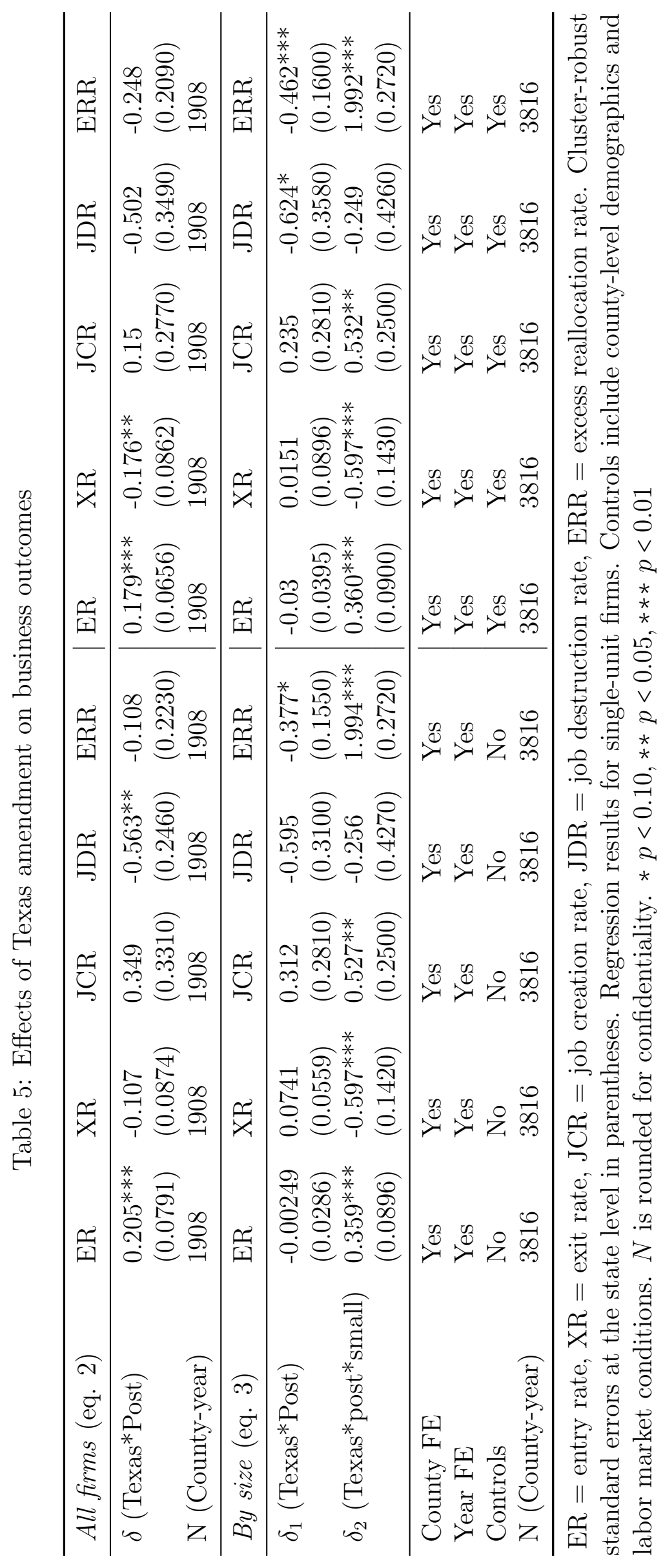


Figure 3: Entry and exit rates by firm size

Entry Rate (Non-Small)

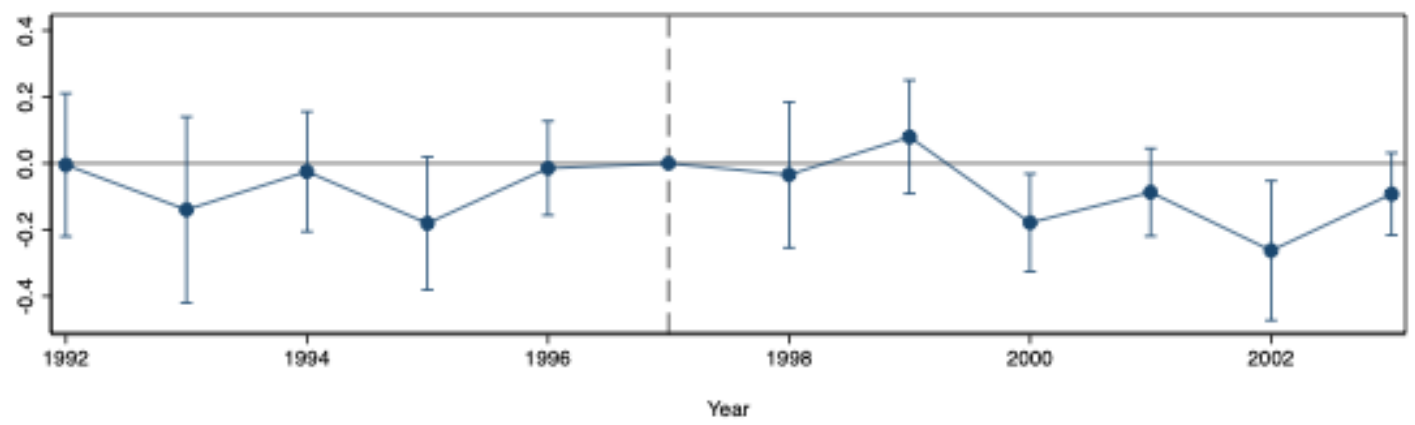

Entry Rate (Small)

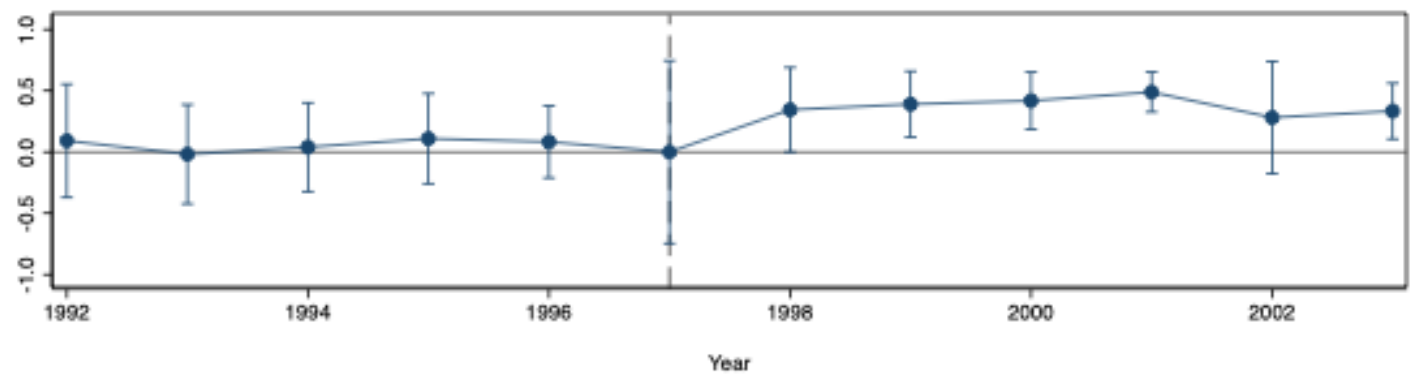

$95 \%$ Confidence Intervals

Controls: Yos

Exit Rate (Non-Small)

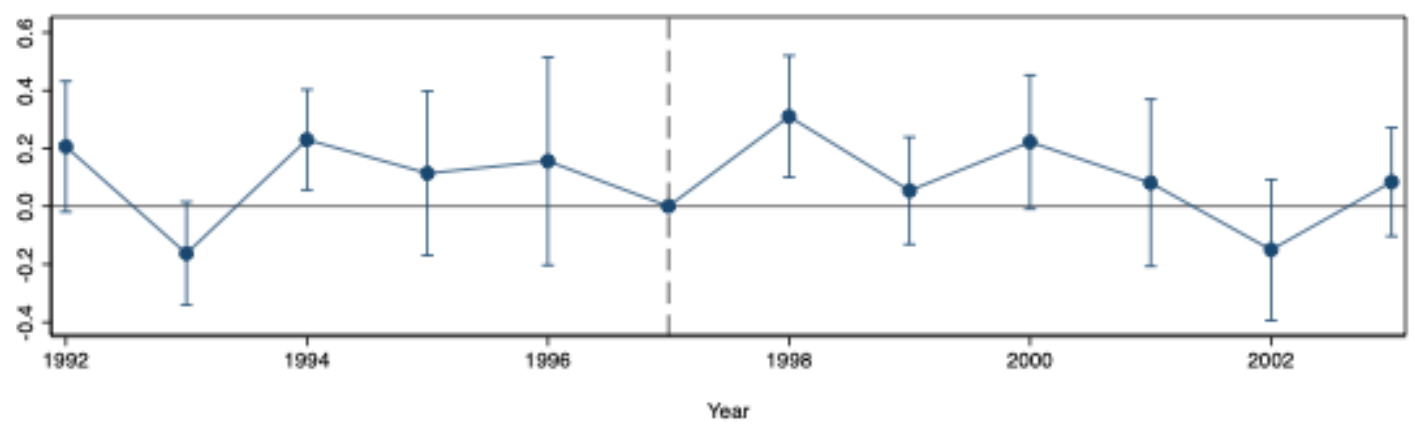

Exit Rate (Small)

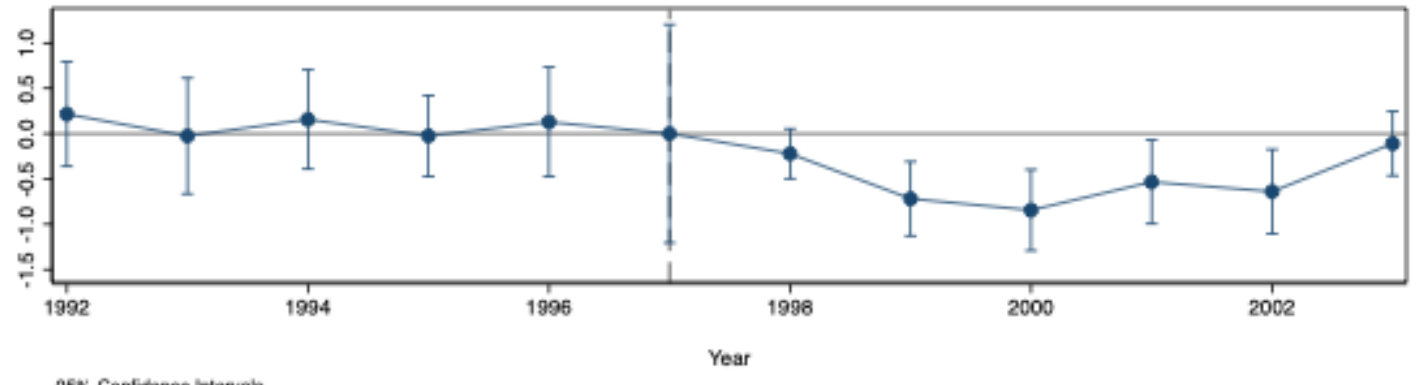

95\% Confidence Intervals 
Figure 4: Job destruction and creation rates by firm size

Job Creation Rate (Non-Small)

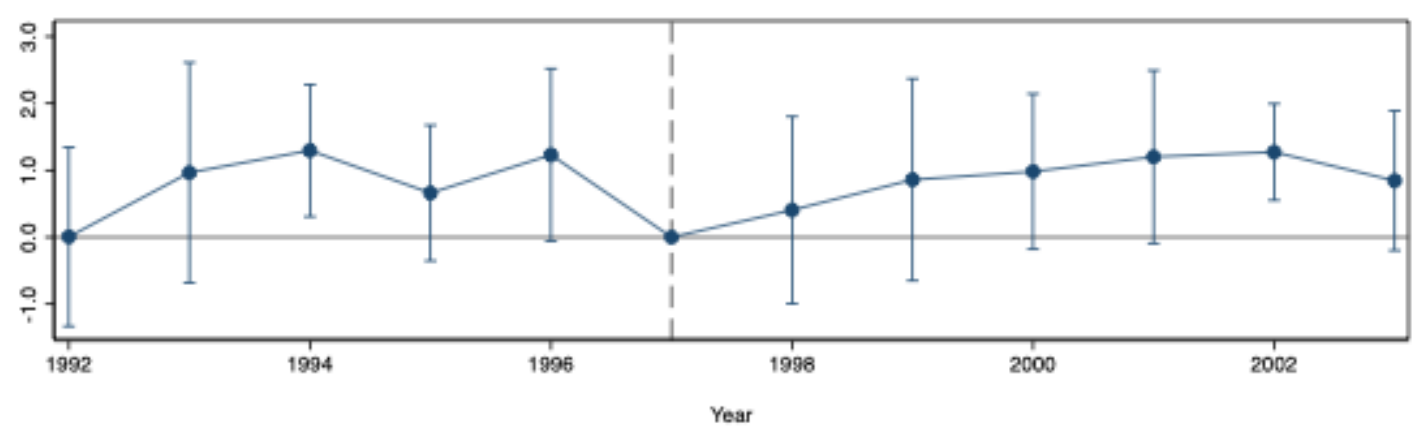

Job Creation Rate (Small)

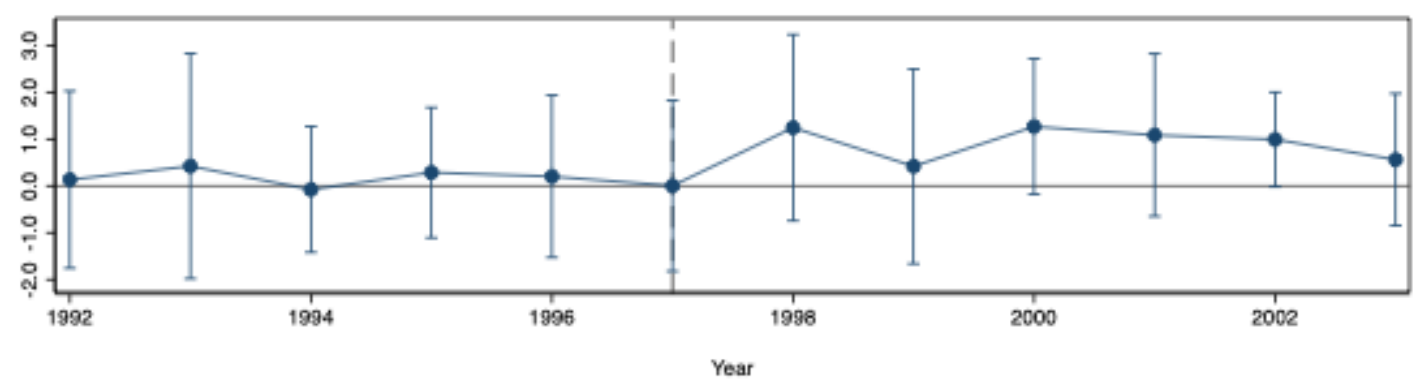

95\% Confidence Intervals
Controls: Yas

Job Destruction Rate (Non-Small)

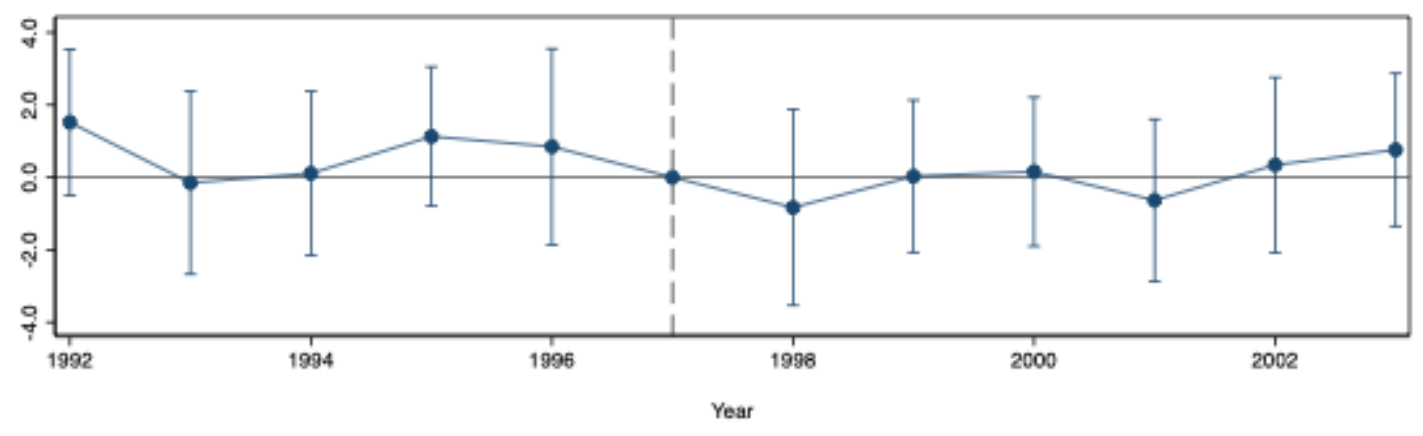

Job Destruction Rate (Small)

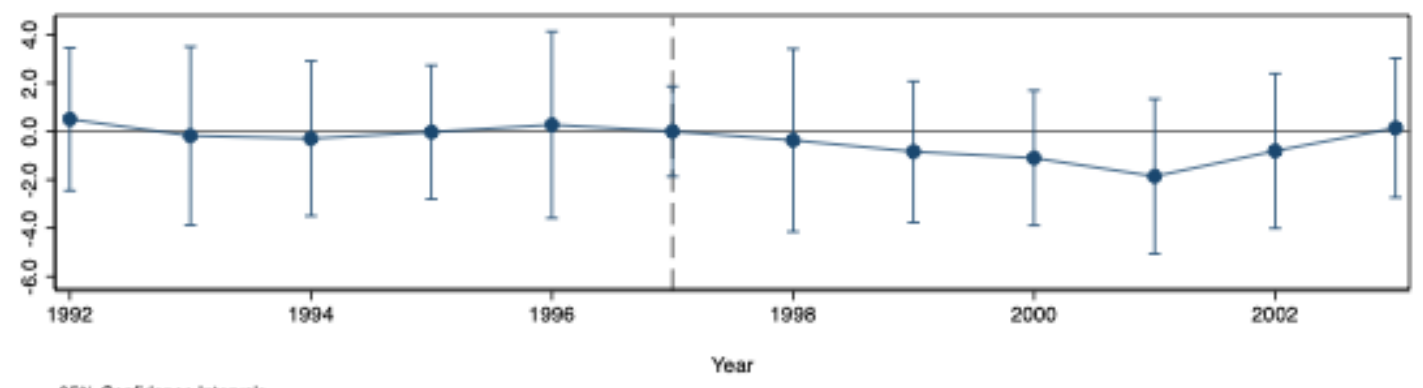

$95 \%$ Confidence Intervals
Controts: Yes 


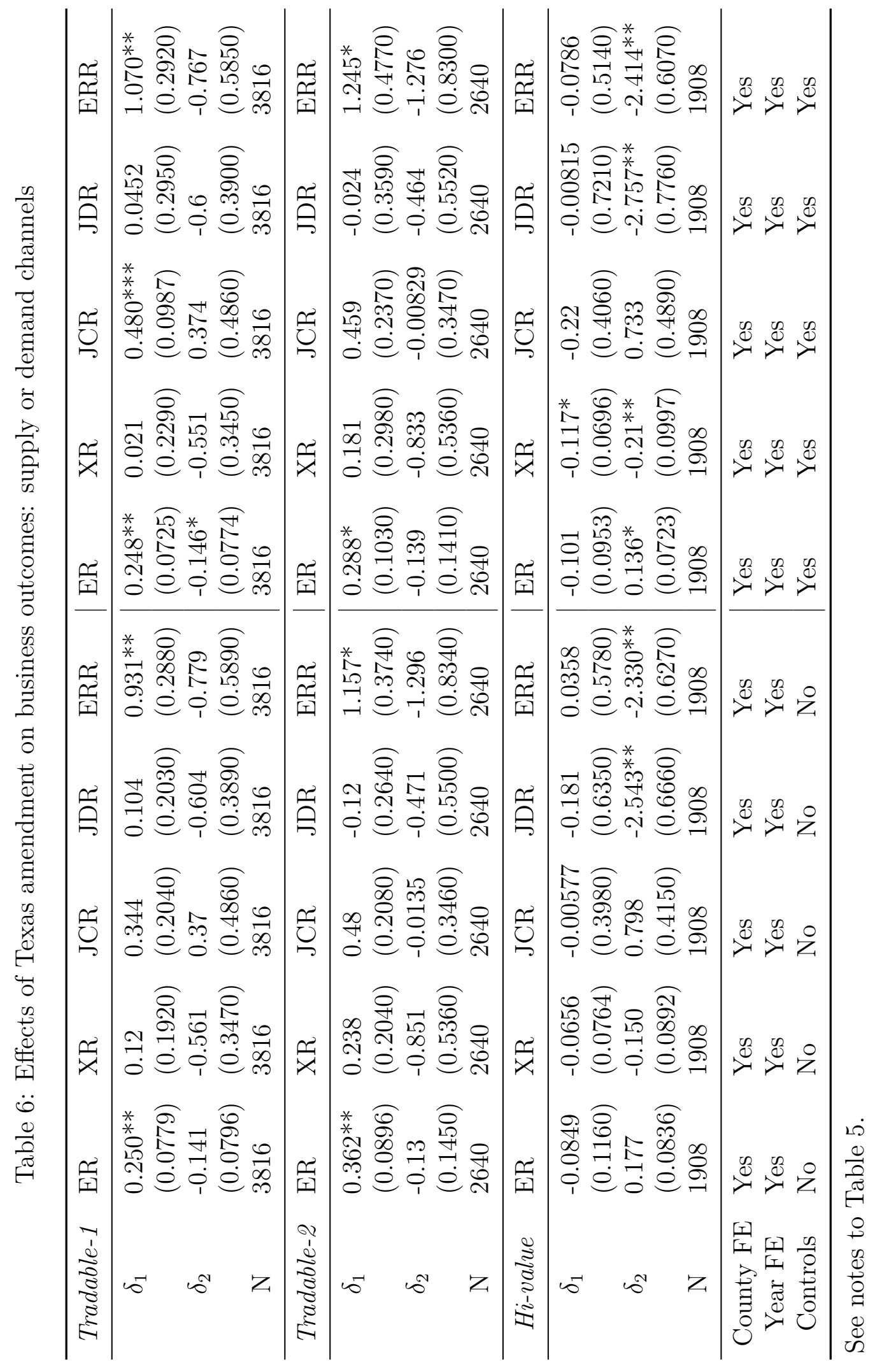

